\title{
PENERAPAN MEDIA “TELENG" UNTUK MENINGKATKAN HASIL BELAJAR SISTEM GERAK MANUSIA
}

\section{APPLICATION OF "TELENG" MEDIA TO INCREASE LEARNING OUTCOMES OF HUMAN LOCOMOTORY SYSTEM}

\author{
TEGUH SOEHARTO
}

SMPN 3 Babelan, kab. Bekasi, Jawa Barat

Received: March 04, 2021
Revised: $\quad$ March 07, 2021
Accepted: March 12, 2021

\begin{abstract}
Minimum completeness criteria for the movement system in humans at SMP Negeri 3 Babelan in 2020 shows learning outcomes. It was caused by the limited media that can be used to learn concepts. Media "Teleng" (tepung lengket) requires students to study the concept in depth, which is a background for conducting this research. The objectives of this study are: (1) to elaborate the learning outcome improvement; (2) to explain the teaching and learning process; and (3) to explain student responses. Teleng is a medium in the form of bones from clay with lots of advantages such as, easy to hand-made, easily-obtained materials, and durable. This study used the $R \& D$ method, with a 4D model. The data were obtained through observation of the learning process, and responses, as well as evaluation of learning outcomes. The research instrument uses learning outcomes test, observation of learning activities and responses. The conclusions are: (1) learning outcomes of the human locomotory system can be improved; (2) Teleng is practically used in the learning process; and (3) Teleng attracts students' attention. The results of this learning innovation media research can be used as an alternative to improve learning outcomes for the concept of the human locomotory system.
\end{abstract}

\section{Abstrak.}

Kriteria ketuntasan minimum (KKM) untuk sistem gerak pada manusia di SMP Negeri 3 Babelan tahun 2020 menunjukkan hasil pembelajaran. Rendahnya hasil belajar disebabkan oleh terbatasnya media yang dapat digunakan siswa untuk mengkaji konsep secara berulangulang, sehingga diperlukan media alternatif untuk mengatasinya. Media "Teleng" (tepung lengket) mewajibkan siswa mengkaji konsep secara mendalam. Hal tersebut melatarbelakangi dilakukannya penelitian. Tujuan penelitian ini adalah: (1) menjelaskan peningkatan hasil belajar sistem gerak manusia setelah menggunakan Media Teleng; (2) menjelaskan pelaksanaan proses belajar mengajar melalui pemanfaatan Media Teleng; dan (3) menjelaskan respon siswa. Media Teleng adalah media peraga berupa tulang tulang penyusun sistem gerak manusia yang terbuat dari berbagai tepung. Kelebihan media ini dibuat sendiri oleh siswa, bahan mudah diperoleh dengan masa pakai yang lama.Penelitian ini menggunakan metode $R \& D$. Model 4D yaitu define, design, develope, disseminate adalah yang digunakan pada penelitian pengembangan ini. Melalui observasi proses belajar mengajar sistem gerak manusia, observasi respon murid dan evaluasi hasil belajar data perkembangan didapatkan. Lembar evaluasi hasil belajar, lembar kerja siswa, lembar observasi kegiatan belajar mengajar dan lembar observasi merupakan instrumen yang dipakai dalam penelitian ini. Simpulan yang didapat adalah: (1) setelah menggunakan media Teleng, hasil belajar sistem gerak manusia dapat ditingkatkan; (2) dalam proses pembelajaran, media Teleng praktis dipakai; (3) media Teleng mendatangkan daya tarik bagi siswa; dan (4) untuk meningkatkan hasil belajar konsep sistem gerak manusia, hasil penelitian media inovasi pembelajaran ini dapat dijadikan alternatif.

Keywords: learning media, learning outcomes, and human locomotory system

Kata kunci: $\quad$ media pembelajaran, "Teleng", hasil belajar, dan sistem gerak manusia

$\left(^{\star}\right)$ Corresponding Author: teguhsoehartompd@gmail.com

How to Cite: Soeharto, T. (2021). Penerapan media "Teleng" untuk meningkatkan hasil belajar sistem gerak manusia. Jurnal Lingkar Mutu Pendidikan, 18 (1), 29-40. https://doi.org/10.54124/jlmp.v18i1.23

\section{PENDAHULUAN}

Pembelajaran sistem gerak manusia di SMP kadang menemui beberapa permasalahan diantaranya adalah media pembelajaran yang terbatas. Contohnya di SMP Negeri 3 Babelan, kabupaten Bekasi jumlah torso rangka manusia yang tersedia di sekolah hanya satu set dan tidak mencukupi 
untuk keseluruhan siswa. Hal seperti ini kemungkinan juga terjadi di banyak sekolah untuk tema pembelajaran yang sama.

Materi sistem gerak manusia merupakan kajian yang sangat menarik karena menyajikan begitu banyak informasi unik dan misteri tentang bagaimana manusia bisa berdiri, bergerak dan bekerja, sehingga sangat menyenangkan untuk dipelajari dan dipahami. Berdasarkan hasil pengamatan semestinya siswa bersemangat dan merasa senang mempelajarinya, namun yang terjadi adalah, siswa ada tidak tahu apa yang harus dilakukan, tidak memperhatikan, tidak menyimak, tidak konsentrasi, atau melakukan kegiatan lainnya saat guru menerangkan materi di papan tulis. Hal ini disebabkan karena media hanya dapat didemonstrasikan. Siswa kurang antusias dan semangat karena hanya melihat, tanpa dapat menyentuh media untuk lebih memahami. Pembelajaran menjadi kurang menarik dan menjadikan siswa bosan, sehingga mengakibatkan pada hasil belajar sistem gerak manusia. Akibatnya pencapaian rata-rata hasil belajar siswa di SMPN 3 Babelan, kabupaten Bekasi hanya sebesar 48,9.

Terdorong keinginan untuk mengatasi keterbatasan tersebut maka perlu dibuat media yang menarik dan dapat dibuat sendiri oleh siswa. Media alternatif yang disusun adalah media tepung lengket (Teleng). Media ini dirancang agar dapat meningkatkan pemahaman konsep dan keterampilan sehingga dapat meningkatkan hasil belajar siswa. "Teleng" sebenarnya telah dikembangkan oleh banyak peneliti dalam bentuk clay (lilin lentur), misalnya penelitian yang dilakukan oleh (Wahyuni 2013,26 ) yang memanfaatkan clay untuk membuat relief, dan juga diadopsi untuk pembelajaran sistem gerak manusia di SMPN 3 Babelan.

Ketertarikan dan pemahaman siswa pada materi konsep sistem gerak manusia dapat dioptimalkan dengan penggunaan media (Widodo 2018, 5). Bahwa media dapat memfasilitasi pemahaman dan penguatan, dapat membangkitkan ketertarikan siswa dalam pembelajaran dan mendukung siswa untuk fokus pada objek pembelajaran ke dalam dunia nyata. Itu juga yang terjadi pada media Teleng.

Kemampuan kognitif serta kemampuan psikomotor siswa yang disajikan dalam bentuk informasi tiga dimensi dengan unsur kebaruan dalam media Teleng merupakan keterpaduan yang ingin dicapai. Kemampuan kognitif siswa, dalam bentuk pemahaman bentuk tulang yang akan dibuatnya secara lebih cermat. Kemampuan psikomotornya diwujudkan dengan membentuk tulang menggunakan tepung sebagai bahan dasarnya. Media ini memiliki keunggulan yaitu bahan bakunya murah dan mudah didapat, mudah dibuat, aman digunakan dalam pembelajaran, dan tahan lama bila disimpan ditempat yang kering. Berdasarkan pengamatan dapat bertahan hingga satu sampai dua tahun.

Teleng adalah media yang disusun sendiri oleh siswa. Diawali dengan memilih jenis tulang yang akan dibuat, kemudian mengolah terigu dan membentuk tulang sesuai rencana, mengeringkan dan menghias media Teleng yang telah jadi dengan cat pewarna, serta menggunakan media tersebut dalam pembelajaran. Saat siswa dilibatkan langsung dalam penggunaan media Teleng diinginkan akan mendorong daya tarik siswa, serta mengoptimalkan pemahaman dan hasil belajar pada materi sistem gerak manusia.

Interaksi edukatif dan dominasi siswa diharapkan tumbuh dengan penggunaan media Teleng. Hal tersebut diharapkan mampu meningkatkan hasil belajar sistem gerak manusia pada Siswa SMPN 3 Babelan, Kabupaten Bekasi.

Pada penelitian ini perumusan masalah yang ditetapkan adalah: (1) bagaimana media Teleng dapat meningkatkan hasil belajar sistem gerak manusia? (2) bagaimana pelaksanaan pembelajaran dengan menggunakan media Teleng? (3) bagaimana respon siswa pada digunakannya media Teleng?

Penelitian ini menetapkan tujuannya sebagai berikut: (1) melalui penerapan media Teleng dapat meningkatkan hasil belajar sistem gerak manusia; (2) dengan menggunakan media Teleng dapat meningkatkan keterlaksaan proses pembelajaran; dan (3) meningkatkan respon positif siswa dalam mempelajari sistem gerak manusia.

Harapan terbesar penelitian ini adalah dapat memberikan manfaat pada: (1) melalui penerapan media Teleng mampu meningkatkan hasil belajar sistem gerak manusia; (2) dengan dirancangnya media pembelajaran yang kreatif dan inovatif dapat meningkatkan kompetensi guru; dan (3) sumbangan dalam memperbaiki kualitas pembelajaran di sekolah melalui penerapan media Teleng 
dapat diberikan oleh hasil penelitian ini; serta (4) dapat meningkatkan pengetahuan dan keterampilan dalam penggunaan media Teleng.

Teleng diharapkan akan meningkatkan hasil belajar. Dalam hal ini hasil belajar adalah pengetahuan yang didapat oleh siswa sesudah melalui beberapa pengalaman, yang mencakup pengalamana kognitif, afektif dan psikomotorik (Rusman 2015, 67). Bahwa pengetahuan yang didapat oleh siswa tidak hanya terbatas pada penguasaan konsep mata pelajaran saja, akan tetapi meliputi hal lain, seperti penguasaan kebiasaan, kesenangan, minat bakat, persepsi, harapan, keinginan dan cita-cita. Jadi hasil belajar adalah kemampuan yang dimiliki oleh siswa setelah melewati kegiatan belajar.

IImu pengetahuan alam (IPA) mempelajari gejala-gejala alam, yang dikembangkan melalui observasi dan eksperimen dalam metode ilmiah, sehingga diperlukan sikap ilmiah yang meliputi jujur, keingintahuan, terbuka dan sebagainya (Trianto 2015, 136). Jadi dapat dibuat kesimpulan bahwa peristiwa-peristiwa yang terjadi di alam dipelajari dalam IPA melalui rangkaian metode ilmiah.

Sistem gerak manusia merupakan bagian dari pembelajaran IPA yang mempelajari organ-organ penyusun sistem gerak, yang menyebabkan tubuh dapat bergerak dan bekerja. Sistem gerak manusia terdiri dari dua alat gerak yaitu alat gerak pasif berupa rangka dan tulang dan alat gerak aktif berupa otot (Kurniasih 2018, 41). Pergerakan tubuh manusia merupakan adanya kerja sama yang kompak antara sistem rangka dan sistem otot. Jadi hasil belajar sistem gerak manusia adalah kemampuan yang dimiliki oleh siswa setelah melewati kegiatan belajar yang membahas tentang organ-organ penyusun sistem gerak, yang menyebabkan tubuh dapat bergerak dan bekerja.

Manfaat media pembelajaran meliputi: (1) untuk pesan yang bersifat verbalistik menjadi lebih jelas; (2) kemampuan indra menjadi lebih banyak, termasuk kemampuan ruang dan waktu; (3) siswa menjadi lebih banyak aktivitasnya; (4) mengurangi keberagaman sifat, demikian juga pada pengalaman dan latar belakang murid. Media diinginkan mampu menghasilkan pesan yang verbal, menjadikan siswa lebih aktif dan menyeragamkan sifat, pengalaman dan latar belakang murid agar dapat mempunyai pemahaman konsep yang sama (Sadirman 2012).

Dengan berbahan dasar tepung, media Teleng menjadi media inovatif. Karena alasan mudah didapat, murah, tidak berbahaya, dan mudah dibentuk maka tepung menjadi pilihan dalam pembuatan media ini. Tepung akan dibentuk sesuai dengan materi yang akan disampiakan setelah sebelumnya diolah sedemikian rupa dengan beberapa bahan tambahan.

Penelitian akan bersifat menemukan, membuktikan, dan mengembangkan. Penemuan menggunakan data yang baru dan belum pernah diketahui merupakan hakikat penelitian sebagai penemuan. Menggunakan data untuk membuktikan adanya ketidakpercayaan terhadap informasi adalah pentingnya penelitian sebagai pembuktian. Akan memperdalam dan memperluas pengetahuan yang telah adalah keinginan penelitian sebagai pengembangan (Sugiyono 2017, 5).

Penelitian dan pengembangan, serta validasi produk pendidikan adalah yang dimaksid dengan research and developtmen ( $\&$ \&) (Sanjaya 2014, 219). Melalui uji desain dan uji coba produk di lapangan yang merupakan produk pendidikan yang dapat berbentuk hardware maupun software sehingga didapatkan efektivitas dan kebermanfaatannya.

Penelitian ini dapat melalui tahapan pengembangan yang terdiri dari: (1) mengamati kebutuhan guru dan siswa dalam proses belajar mengajar; (2) menghimpun sejumlah data dilakukan melalui analisis terhadap materi dan media pembelajaran yang akan dikembangkan; (3) merancang prototype media; (4) dilakukan validasi materi, media, dan bahasa dari pakarnya; (5) pemberian kritik dan saran dari validator menjadi dasar perbaikan rancangan; (6) uji coba kepada peserta didik perlu dilakukan pada media; serta (7) revisi akhir produk sesudah uji coba didapatkan hasil yang memberikan manfaat (Sugiyono 2017, 409).

Media Teleng sebagai pelengkap proses belejar mengajar mata pelajaran IPA materi sistem gerak manusia pada siswa SMPN 3 Babelan, kabupaten Bekasi, kelas VIII-1 menjadi hasil akhir dari penelitian ini. Dengan menggunakan media Teleng ini diinginkan berkembangnya interaksi edukatif siswa, menghasilkan siswa yang lebih aktif dalam proses belajar mengajar. 


\section{METODE PENELITIAN}

Metode penelitian yang digunakan adalah metode Research and Development (R \& D) dengan desain penelitian pengembangan model 4D (Four D Models) yang disampaikan oleh Thiagarajan di tahun 1974 (Sugiyono 2017, 291). Desain penelitian pengembangan 4D meliputi pendefinisian (define), perancangan (design), pengembangan (develop), dan diseminasi (disseminate).

Tahap pendefinisian merupakan tahap untuk menetapkan dan menginfentarisasi kebutuhankebutuhan dalam proses pembelajaran terkait media yang akan dikembangkan. Tahap ini mengalami beberapa tahapan yaitu: kajian awal (front-end analysis), kajian siswa (leaner analysis), kajian tugas (task analysis), kajian konsep (concept analysis), dan kaijan tujuan (specifying instructional objectives).

Langkah perancangan merupakan tahap untuk merancang media yang akan dikembangkan, agar dapat digunakan dalam proses pembelajaran. Tahap ini tersusun oleh beberapa langkah meliputi: penyusunan tes (criterion-test construction), pemilihan media (media selection), pemilihan format (format selection), dan desain awal (initial design).

Tahap pengembangan merupakan tahap menghasilkan media pembelajaran yang akan divalidasi dan diujicobakan kepada siswa dalam proses pembelajaran. Tahap ini tersusun dalam dua langkah yaitu validasi ahli (expert appraisal) dan uji coba produk (development testing). Tahap diseminasi merupakan merupakan tahap akhir dari penelitian pengembangan. Pada tahap ini media dipromosikan pada kalangan tertentu agar dapat diterima dan digunakan.

Pengembangan media Teleng dalam penelitan ini menggunakan desain 4D. Pada tahap pedefinisian dikaji kebutuhan dalam mengoptimalkan hasil belajar pada konsep sistem gerak manusia. Pada tahap perancangan disusun rencana media yang akan dikembangkan dalam upaya meningkatkan hasil belajar tersebut, disusun rencana pembuatan media Teleng. Pada tahap pengembangan dilakukan pembuatan media Teleng yang kemudian diujikan penggunaannya kepada siswa, dilakukan pengamatan dan penyempurnaan. Pada tahap diseminasi, media ini disampaikan dalam forum diskusi guru-guru IPA sekabupaten Bekasi.

Adapun prosedur pengembangan media Teleng dapat dilihat pada gambar desain pengembangan media Teleng berikut ini.

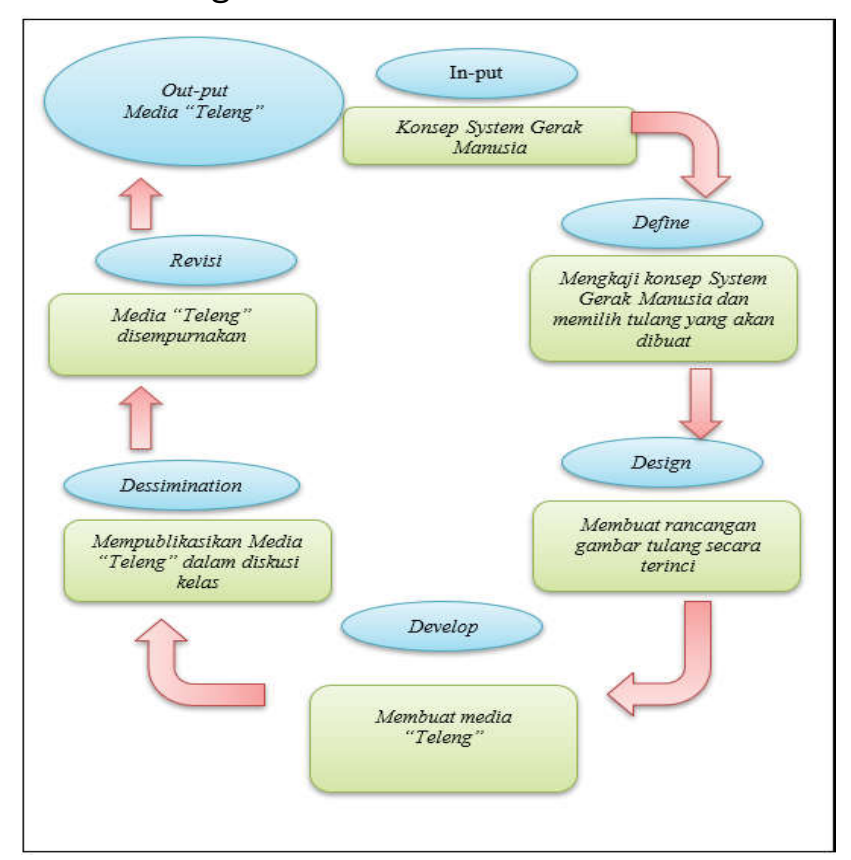

Gambar 1. Desain pengembangan media "Teleng"

Penelitian ini dilakukan di SMPN 3 Babelan, kabupaten Bekasi, Jawa Barat, tepatnya di bulan Februari sampai April 2020, semester genap, tahun pelajaran 2019-2020. Subyek yang menjadi sasaran adalah murid kelas VIII-1 SMPN 3 Babelan sebanyak 30 siswa, jumlah siswa 6 orang dan siswa perempuan berjumlah 24 orang. Penelitian ini dibantu oleh dua orang observer guru IPA yang membantu mengamati saat proses berlangsung. 
Adapun proses pembuatan media Teleng dapat dilihat pada tabel berikut ini.

Tabel 1. Proses pembuatan media "Teleng"

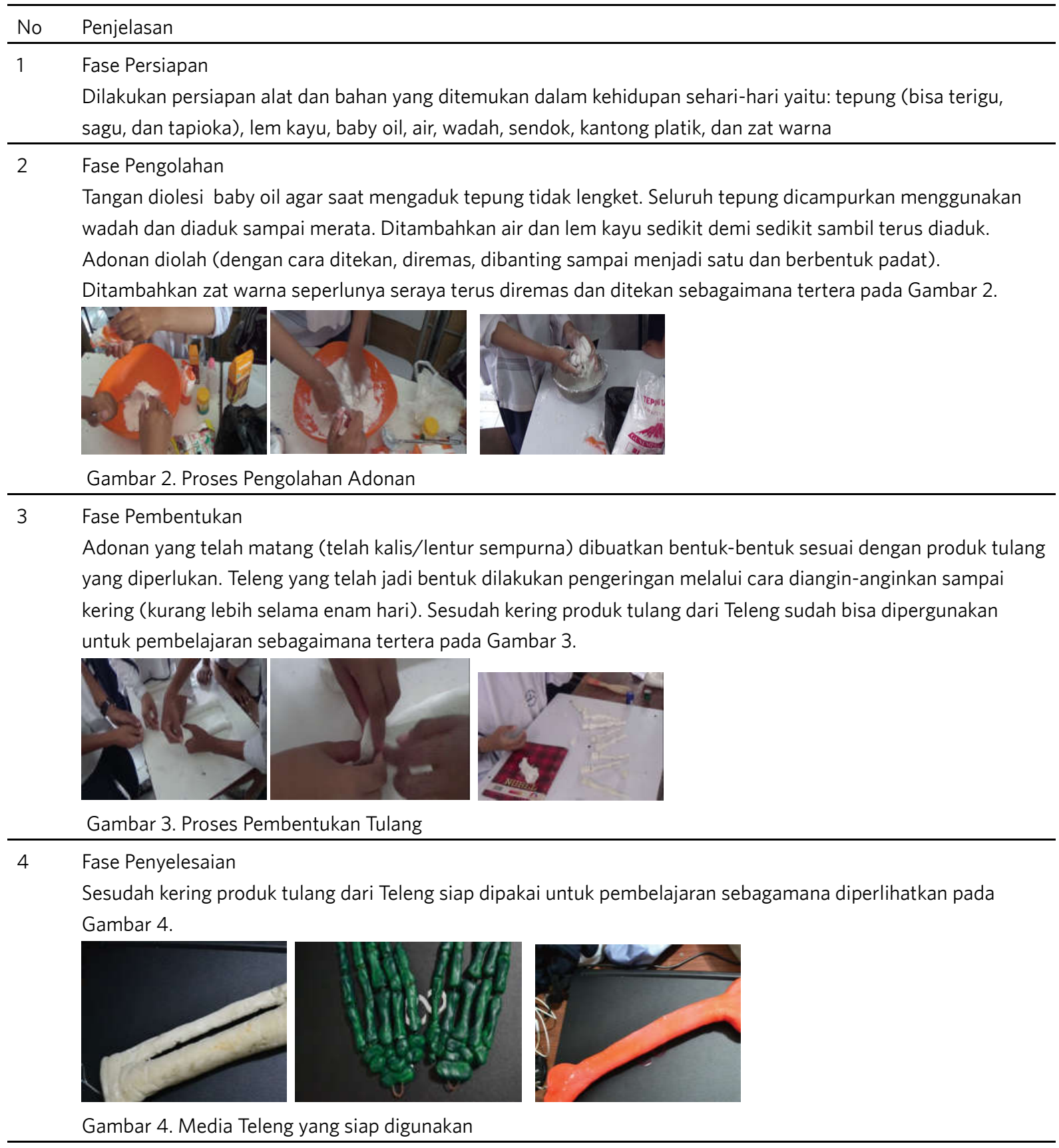

Teknik pengumpulan data dalam penelitian ini dilakukan dalam dua cara, yaitu secara observasi dan tes hasil belajar. Observasi dilakukan dengan mengadakan pengamatan pada saat proses pengembangan media dan proses belajar mengajar. Observasi dilakukan juga melalaui wawancara untuk mengetahui respon siswa terhadap penggunaan media Teleng. Hasil belajar siswa diketahui melalui teknik tes hasil belajar pada materi sistem gerak manusia.

Alat pengumpul data yang digunakan untuk mengumpulkan data hasil belajar berupa lembar pretest dan postest. Untuk data praktikalitas digunakan lembar observasi kegiatan belajar mengajar, sedangkan untuk respon siswa digunakan lembar wawancara respon siswa. Bentuk soal yang digunakan pada pretest dan postest adalah soal pilihan ganda dengan jumlah 30 butir pada tiap tesnya (soal terkait subkonsep tulang pipa, tulang pipih, dan tulang pendek).

Data yang terkumpul akan dilakukan secara kuantitatif dan kualitatif. Data hasil belajar akan dianalisis secara kuantitatif dengan membandingkan hasil belajar pada saat pretest dengan postest. Data hasil tes berupa rata-rata hasil belajar dan ketuntasan belajar. Data praktikalisasi media, data 
respon siswa, dan data efektivitas media adalah kajian data yang dipakai. Data praktikalitas serta data respon siswa akan dianalisis secara kuantitatif, kemudian akan diartikan secara kualitatif.

Penelitian ini dikatakan berhasil bila rata-rata hasil belajar sistem gerak manusia yang diperoleh siswa kelas VIII-1 SMPN 3 Babelan telah mencapai minimal 75\% dan diikuti oleh ketuntasan belajar siswa sebesar $75 \%$.

\section{HASIL DAN PEMBAHASAN}

Proses pengembangan media Teleng menggunakan desain penelitian pengembangan model 4D (four D models) yang dideskripsikan oleh Thiagarajan di tahun 1974 (Sugiyono 2017, 291). Desain penelitian pengembangan 4D terdiri dari pendefinisian (define), perancangan (design), pengembangan (develop), serta diseminasi (disseminate).

Langkah define yang dilaksanakan pada kegiatan ini untuk tujuan menentukan dan mengumpulkan informasi yang dibutuhkan terkait dengan media Teleng yang akan dikembangkan. Pada analisis awal dilakukan kajian pada permasalahan yang ada dimana ditemukan adanya hasil belajar siswa yang rendah pada konsep sistem gerak manusia. Fakta-fakta yang ada di sekolah dikumpulkan untuk mencari kemungkinan penyebab dari rendahnya hasil belajar tersebut. Hasil wawancara dengan guru IPA diperoleh penjelasan bahwa untuk mengajarkan konsep sistem gerak manusia digunakan metode ceramah dan demonstrasi. Hal tersebut dilakukan karena jumlah torso kerangka manusia hanya ada satu sehingga siswa hanya mempelajarinya sepintas.

Pada analisis siswa yang dilakukan melalui wawancara dengan beberapa siswa terkait konsep sistem gerak manusia didapatkan keterangan bahwa siswa bingung dan sulit dalam mempelajari konsep tersebut. Siswa kesulitan mempelajari bentuk dan nama dari setiap bagian alat gerak, karena banyak ragam dan nama asing yang harus diingat. Selain itu siswa hanya mempelajarinya sepintas pada saat guru mendemonstrasikan di depan kelas sehingga siswa menjadi malas untuk mempelajari ulang konsep tersebut melalui buku.

Pada analisis tugas dilakukan kajian pada kompetensi isi (KI) serta kompetensi dasar (KD) yang dalam konsep sistem gerak manusia. Kompetensi yang harus dimiliki oleh siswa adalah mampu memahami dan menjelaskan nama, bentuk, fungsi dan jenis tulang penyusun sistem gerak manusia. Ketercapaian kompetensi tersebut menjadi pertimbangan dan tujuan dalam mengembangkan media Teleng.

Pada analisis konsep dilakukan identifikasi dan disusun secara sistematis bagian-bagian utama materi pembelajaran yang akan dikembangkan dalam media Teleng. Analisis konsep dibuat dalam bentuk peta konsep yang akan menjelaskan macam-macam tulang berdasarkan bentuknya dan tulang-tulang penyusun alat gerak.

Analisis terakhir pada tahap define adalah analisis tujuan pembelajaran. Pada analisis ini ditetapkan tujuan pembelajaran yang akan dicapai dalam pengembangan media Teleng dan indikator keberhasilan yang ingin dicapai. Adapun tujuan pembelajaran yaitu siswa dapat menjelaskan nama, bentuk, fungsi, dan letak tulang dalam sistem gerak manusia yang ditunjukkan oleh rata-rata hasil belajarnya. Indikator keberhasilan pengembangan media Teleng sebesar 75 .

Tahap design pada penelitian ini merupakan tahap merancang media Teleng agar dapat digunakan dalam pembelajaran konsep sistem gerak manusia. Langkah awal dari tahap design adalah menyusun instrumen pretest berdasarkan tujuan pembelajaran yang telah ditetapkan sebelumnya. Instrumen ini menjadi dasar untuk mengukur kemampuan siswa berupa kemampuan kognitif, psikomotor, respon, maupun produk. Langkah selanjutnya adalah melakukan pemilihan media yang akan dikembangkan yang disesuaikan dengan karakter konsep yang dibahasa dan kebutuhan siswa. Media yang akan dikembangkan harus sesuai dengan analisis siswa, analisis konsep, analisis tugas, karakter siswa yang akan menggunakan media, serta rencana penyebaran media yang telah dibuat sesuai dengan langkah yang sudah dikerjakan pada tahap define sebelumnya.

Langkah selanjutnya adalah melakukan pemilihan format pengembangan yang meliputi merancang isi pembelajaran, memilih proses pendekatan, merancang bentuk media Teleng dalam bentuk layout berikut penjelasannya. Layout rancangan media Teleng yang telah dibuat ini diserahkan kepada ahli untuk diberikan masukan dan perbaikan. Dalam hal ini penelitian bekerja sama dengan seorang doktor 
teknologi pendidikan yang menjadi pengawas pembina sekolah dan seorang magister manajeman pendidikan yang menjadi instruktur nasional kurikulum 2013. Masukan dan saran dari ahli digunakan untuk memperbaiki rancangan media Teleng.

Tahap develop pada penelitian ini merupakan tahap pembuatan media Teleng yang dilakukan oleh siswa berdasakan rancangan yangtelah diperbaiki pada tahap sebelumnya. Proses pembuatan media Teleng telah dijelaskan sebelumnya. Media Teleng telah jadi kembali dinilai oleh ahlinya, untuk diketahui apakah media tersebut telah layak atau tidak untuk diterapkan. Hasil penilaian ini akan digunakan sebagi perbaikan dari produk media yang dikembangkan. Setelah perbaikan media Teleng diuji coba kepada siswa melalui proses belajar mengajar di kelas sebagaimana terlihat pada Gambar 5 .

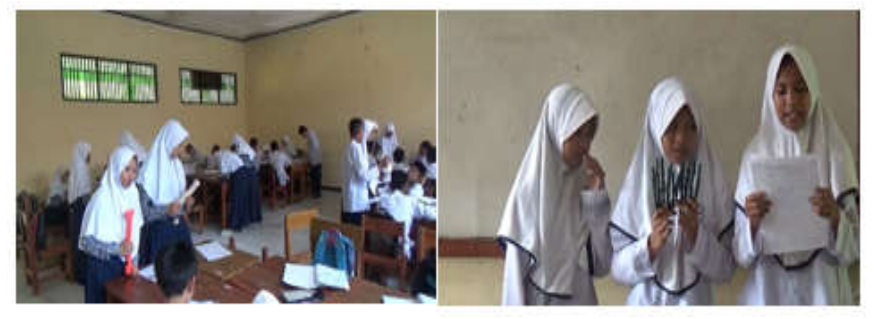

Gambar 5. Uji coba media Teleng

Tahap akhir dari proses pengembangan media Teleng adalah tahap disseminate. Pada tahap ini media Teleng didiseminasikan dan dipromosikan kepada guru-guru IPA sekabupaten Bekasi melalui forum musyawarah guru mata pelajaran (MGMP) IPA kabupaten Bekasi.

Penelitian ini menekankan pada peningkatan hasil belajar sistem gerak manusia dengan media Teleng yang digunakan. Keterlaksaan pembelajaran sistem gerak manusia memanfaatkan media Teleng serta respon siswa terhadap pemakaian media Teleng.

Sebagai perhatian awal pada kegiatan ini adalah untuk menerangkan peningkatan hasil belajar sistem gerak manusia setelah menggunakan media Teleng. Kondisi awal hasil belajar siswa pada konsep sistem gerak masih rendah, dibawah nilai KKM yang telah ditetapkan. Data kondisi awal dapat dilihat pada Tabel 2.

Tabel 2. Hasil belajar siswa awal penelitian

\begin{tabular}{lll}
\hline & \multicolumn{1}{c}{ Jenis Data } & Nilai \\
\hline 1. & Rata-rata hasil belajar & 48,97 \\
2. & Ketuntasan belajar & $6,67 \%$ \\
3. & Nilai terendah & 45,00 \\
4. & Nilai tertinggi & 80,00 \\
5. & Kategori & kurang \\
\hline
\end{tabular}

Pada pretest didapatkan hasil belajar siswa rata-rata mencapai 48,97 dan nilai ketuntasan belajar diperoleh $6,67 \%$. Hal ini berarti hanya ada 2 siswa dari 30 siswa yang memiliki nilai diatas KKM yang sebesar 75. Hasil belajar yang diperoleh di awal penelitian termasuk kategori kurang dibandingkan dengan nilai KKM.

Pada kelompok soal tulang pipa siswa masih kesulitan dalam menyebutkan bagian-bagian pembentuk tulang pipa, seperti pada contoh soal berikut. Sebutkan bagian-bagian tulang humerus, pada Gambar 6 di berikut ini.

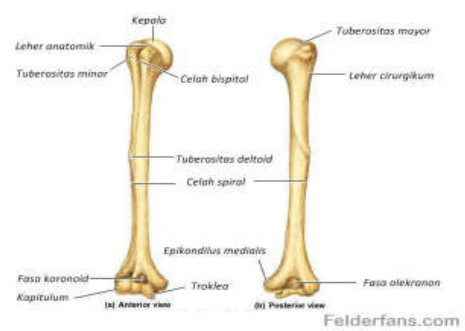

Gambar 6. Contoh kelompok tulang pipa 
Pada kelompok tulang pipih siswa masih kesulitan dalam menjelaskan fungsi tulang pipih, seperti pada contoh soal berikut. Jelaskan fungsi tulang pipih yang terdapat pada tulang rusuk, seperti terlihat pada Gambar 7 berikut ini.

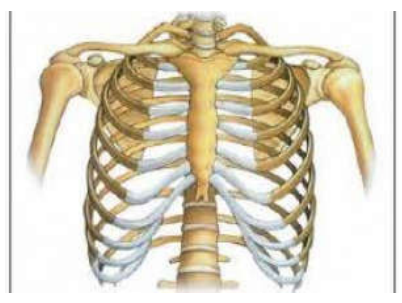

Gambar 7. Contoh kelompok tulang pipih

Pada kelompok tulang pendek siswa masih kesulitan dalam memberikan contoh tulang pendek seperti pada contoh soal berikut. Selain ruas tulang belakang seperti terlihat pada Gambar 8 berikut ini yang merupakan tulang pendek. Sebutkan tulang apa saja yang termasuk tulang pendek.

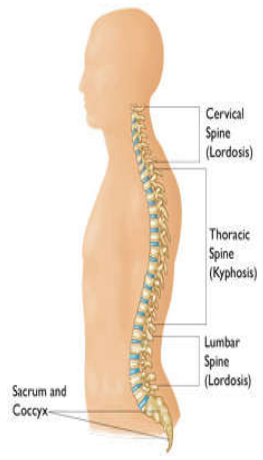

Gambar 8. Contoh kelompok tulang pendek

Kondisi akhir hasil belajar siswa pada konsep sistem gerak menggunakan media Teleng sudah baik. Sudah melampaui nilai KKM yang telah ditetapkan. Data kondisi akhir dapat dilihat pada Tabel 3.

Tabel 3. Hasil belajar siswa akhir penelitian

\begin{tabular}{clc}
\hline No & \multicolumn{1}{c}{ Jenis Data } & Nilai \\
\hline 1. & Rata-rata hasil belajar siswa & 80,13 \\
2. & Ketuntasan belajar & $90,00 \%$ \\
3. & Nilai Terendah & 70,00 \\
4. & Nilai Tertinggi & 90,00 \\
5. & Kategori & Baik \\
\hline
\end{tabular}

Pada postest didapatkan hasil belajar siswa rata-rata mencapai 80,13 dengan dengan ketuntasan belajar yang diperoleh bernilai 90,00\%. Hal tersebut menunjukkan ada 27 siswa dari 30 murid dengan nilai diatas KKM yang bernilai 75. Hasil belajar yang diperoleh di awal penelitian termasuk kategori baik dibandingkan dengan nilai KKM. Siswa tidak lagi mengalami kesulitan dalam menyebutkan dan menjelaskan bentuk, bagian dan fungsi dari tulang penyusun sistem gerak manusia, serta dapat memberikan contoh dari setiap jenis tulang. Rata-rata hasil belajar sebesar 80,13 telah melampaui nilai KKM. Hasil belajar diakhir penelitian sudah termasuk kategori baik. Dapat mengoptimalkan hasil belajar sistem gerak manusia pada hasil belajar menunjukkan pemakaian media Teleng telah mencapai target yang diharapkan.

Murid sudah mampu menyebutkan tulang-tulang pipa apa saja yang dapat menyusun alat gerak manusia, seperti pada contoh soal berikut. Sebutkan tulang-tulang penyusun tungkai atas dan bawah manusia yang digunakan untuk berjalan pada Gambar 9 berikut ini. 


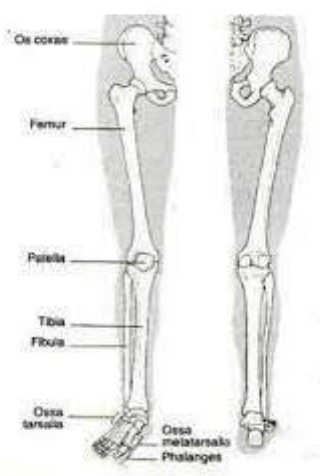

Gambar 9. Contoh tulang pipa penyusun tungkai atas dan bawah

Siswa sudah dapat menjelaskan fungsi tulang pipih, seperti pada contoh soal berikut. Jelaskan fungsi tulang pipih yang terdapat pada pinggul, seperti terlihat pada Gambar 10 berikut ini.

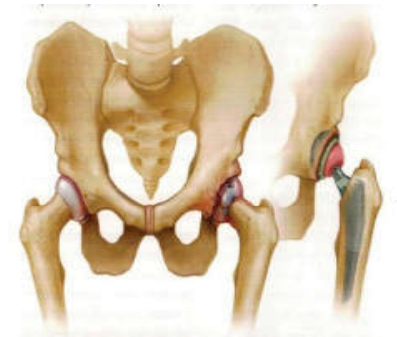

Gambar 10. Contoh tulang pipih

Siswa sudah memberikan contoh tulang pendek seperti pada contoh soal berikut. Berikan contoh beberapa tulang pendek penyusun sistem gerak manusia sebagaimana tercantum pada Gambar 11.
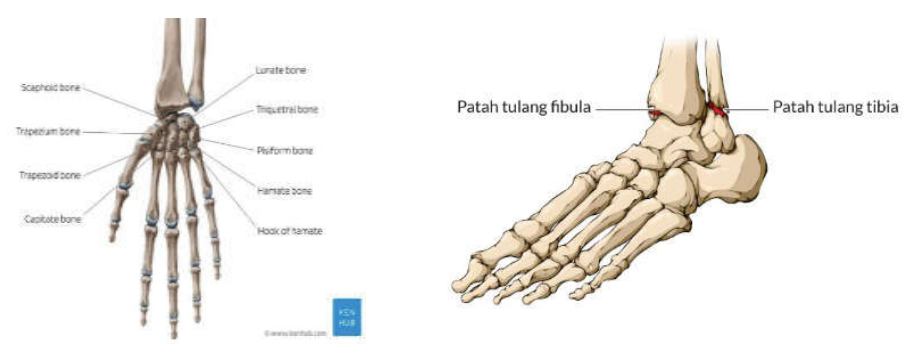

Gambar 11. Contoh Macam-MacamTulang Pendek

Secara keseluruhan hasil belajar sistem gerak manusia ditunjukkan pada gambar di bawah ini.

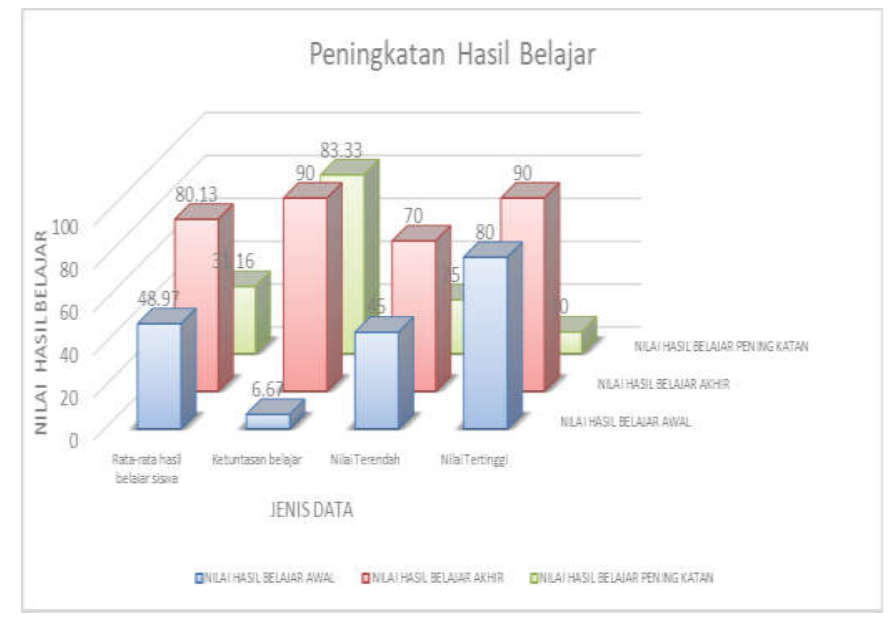

Gambar 12. Grafik peningkatan hasil belajar sistem gerak manusia 
Kenaikan rata-rata hasil belajar sistem gerak manusia sebesar 31,16 poin. Dari rata-rata hasil belajar di awal penelitian 48,97 menjadi rata-rata hasil belajar di akhir akhir penelitian 80,13. Rata-rata hasil belajar sistem gerak manusia sebelum menggunakan media Teleng masih rendah. Rata-rata hasil belajar sistem gerak manusia 48,97.

Terjadi peningkatan $63,63 \%$ sesudah digunakan media Teleng. Nilai hasil belajar rata-rata menjadi 80,13 . Kenaikan nilai ditunjukkan juga pada nilai tertinggi, nilai terendah, dan ketuntasan belajar murid. Pada nilai terendah di awal kegiatan bernilai 45 menjadi naik 55,56\% sehingga bernilai 80 . Pada nilai tertinggi di awal bernilai 80 menjadi naik $12,50 \%$ sehingga bernilai 90 . Pada ketuntasan belajar materi sistem gerak manusia juga menjadi naik dari 2 siswa yang tuntas di awal penilaian akhirnya berkurang dalam 27 murid tuntas.

Adanya kewajiban pada murid untuk menganalisis dan memahami konsep sistem gerak manusia dengan berulang bisa jadi meningkatkan hasil belajar sistem gerak manusia dengan penggunaan media Teleng. Analisis awal diberlakukan ketika murid menetapkan tulang yang akan dibuat dijadikan media Teleng. Kajian kedua, saat siswa mengamati, menganalisis, dan memahami bentuk tulang yang dipilih secara terinci. Kajian ketiga saat siswa membentuk tulang dengan menggunakan terigu. Kajian keempat saat siswa mempresentasikan tulang yang dibuat. Kajian yang menjadi penutup adalah ketika dipakai media Teleng dalam pembelajaran.

Dalam mempelajari dan mengoptimalkan hasil belajar sistem gerak manusia, teleng menjadi media tiga dimensi yang mampu membantu murid. Khususnya konsep sistem gerak manusia media ini bisa dipakai dan digunakan dalam menyampaikan materi pelajaran. Mampu meningkatkan pembelajaran murid adalah salah satu kegunaan media tiga dimensi (Chou 2017, 1060).

Penjelasan tersebut mendeskripsikan bahwa media Teleng yang dikembangkan bersifat efektif. Pada konsep sistem gerak manusia pembelajaran yang menggunakan media Teleng dapat mengoptimalkan hasil belajar murid.

Analisis praktikalitas digunakan untuk mengetahui seberapa efektif dan praktisnya media Teleng dalam proses belajar mengajar. Analisis ini dilakukan melalui observasi pelaksanaan RPP. Hasil analisis dapat memperlihatkan bahwa proses belajar mengajar dengan memanfaatkan media Teleng dapat dilaksanakan sesuai dengan rencana yang ada dalam RPP. Hal tersebut dapat dilihat pada Tabel 4.

Tabel 4. Analisis praktikalitas media Teleng

\begin{tabular}{clc}
\hline No & Kriteria & Skor \\
\hline 1 & Skor perolehan & 42,5 \\
2 & Skor maksimum & 44,0 \\
3 & \% praktikalitas & $96,5 \%$ \\
4 & Kategori & Sangat Praktis \\
\hline
\end{tabular}

Hasil Tabel 4 menunjukkan besarnya nilai kepraktisan sebesar 96,50\% dengan penjelasan bahwa media Teleng praktis sekali bila manfaatkan dalam mengimplementasikan RPP di pembelajaran konsep sistem gerak manusia pada siswa kelas VIII-1 di SMP Negeri 3 Babelan, kabupaten Bekasi.

Observasi pembelajaran pada aspek keterlaksanaan pembelajaran yang dilakukan oleh dua orang ahli dan seorang observer adalah koordinator pengawas sekaligus pengawas pembina di Dinas Pendidikan kabupaten Bekasi. Seorang observer yang dilibatkan juga merupakan instruksur nasional kurikulum 2013. Pada aspek ini meliputi tahap pendahuluan, kegiatan inti, dan penutup. Tahap pendahuluan terdiri dari: (1) dijelaskannya tujuan pembelajaran, acuan, dan orientasi; (2) direncanakannya pengembangan media; dan (3) dijelaskannya pemakaian media. Rata-rata hasil observasi beroleh nilai 4 yang berarti amat praktis didapatkan pada tahapan ini. Memfasilitasi, mengobservasi dan mengevaluasi define, design, develop, dan revisi dilakukan pada kegiatan ini. Hasil observasi memiliki rata-rata 3,50 pada tahap kegiatan inti yang berarti amat praktis. Di kegiatan penutup yang terdiri atas pembuatan resume dan penugasan portofolio mendapatkan nilai 4 yang berarti amat praktis. Semua aspek memperoleh rata-rata pada seluruh aspek bernilai 38,5 dengan kategori amat praktis.

Simpulan analisis pelaksanaan pembelajaran adalah media Teleng yang dimanfaatkan pada kegiatan belajar mengajar secara praktis pada konsep sistem gerak manusia. Berdasarkan angket 
respon siswa yang diberikan diakhir kegiatan, diperoleh data bahwa siswa lebih mudah memahami konsep-konsep sistem gerak manusia. Hal itu dikarenakan siswa berinteraksi langsung membuat media dan berulang-ulang mengkaji konsep sebelum membuat media Teleng. Respon siswa terhadap penggunaan media Teleng terlihat pada Tabel 5.

Tabel 5. Analisis respon siswa terhadap penggunaan media Teleng

\begin{tabular}{clc}
\hline No & \multicolumn{1}{c}{ Kriteria } & Skor \\
\hline 1 & Nilai rata-rata & 28,00 \\
2 & Skor total & 196 \\
3 & Skor Maksimum & 210 \\
4 & Persentase responden setuju & $93,33 \%$ \\
5 & Kategori & Sangat menarik \\
\hline
\end{tabular}

Berikut ini respon yang diperoleh dari observasi tanggapan murid pada pemakaian media Teleng dalam proses belajar mengajar konsep sistem gerak manusia: (1) dengan dimanfaatkannya media Telang, murid merasa senang saat melakukan proses belajar mengajar; (2) dalam mempelajari sistem gerak manusia, media Teleng menarik untuk dimanfaatkan; (3) dalam mempelajari sistem gerak manusia media Teleng pun mudah dipahami dan digunakan; (4) media Teleng menjadikan konsep sistem gerak manusia menjadi lebih jelas; (5) media Teleng meningkatkan proses pembelajaran; serta (6) pada konsep IPA yang lain siswa juga tertarik memakai media Teleng.

Respon siswa tinggi terhadap penggunaan media Teleng akan mendorong minat dan keinginan siswa untuk mempelajari konsep sistem gerak manusia secara lebih baik. Pada akhirnya akan membantu siswa dalam meningkatkan hasil belajarnya.

Pemanfaatan media saat pembelajaran mampu meningkatkan minat murid. Itu juga yang terjadi dalam pembelajaran sistem gerak manusia dengan penggunaan media Teleng. Minat murid pada pemanfaatan media Teleng amat tinggi. Itu ditunjukkan dengan nilai rata-rata murid yang memberi respon positif di tiap pernyataan yang diberikan sejumlah 28 dari 30 murid dalam arti sebanyak 93,33\% dengan kategori amat tertarik.

Hasil yang meningkat di capaian belajar murid juga diakibatkan dari pemanfaatan media Teleng. Teleng bisa menampilkan media yang menyamai bentuk asli yang menarik untuk dipelajari sehingga bisa menunjang kegiatan pembelajaran. Pendapat yang mengatakan media tiga dimensi merupakan media pembelajaran yang bisa merangsang keinginan murid untuk belajar dan sebagai alat pemberian pesan atau materi pembelajaran adalah sejalan dengan hasil dari penggunaan media Teleng (Pawestri 2016). Memudahkan murid dalam mengenali konsep-konsep sulit yang bersifat kurang konkrit pada materi sistem gerak manusia dengan adanya benda menyerupai bentuk asli nyata menjadikan manfaat dari pemakaian media Teleng.

\section{SIMPULAN DAN SARAN}

Penelitian yang dilaksanakan di SMPN 3 Babelan, kabupaten Bekasi ini mendapatkan simpulan bahwa terjadi peningkatan hasil belajar pada materi sistem gerak manusia dengan dimanfaatkannya media Teleng. Terdapat kenaikan rata-rata hasil belajar sistem gerak manusia sebesar 31,16 poin atau naik 63,63\%. Dari rata-rata hasil belajar di awal penelitian sebesar 48,97 menjadi rata-rata hasil belajar di akhir sebesar 80,13. Ketuntasan belajar murid juga terjadi peningkatan dari dua siswa yang tuntas di awal kegiatan ini menjadi 27 siswa di akhirnya.

Implementasi proses pembelajaran sistem gerak manusia bisa dilaksanakan secara praktis dengan memanfaatkan media Teleng. Pemanfaatan media Teleng juga didukung dengan pernyataan murid terkait dengan minatnya pada media ini. Peserta didik mengatakan merasa lebih senang dan lebih mudah dalam memahami konsep sistem gerak manusia sesudah diimplementasikannya pembelajaran dengan media Teleng.

Dengan simpulan yang sudah diperoleh maka saran yang dapat disampiakna adalah: (1) bisa dijadikan contoh dalam membuat media pembelajaran penggunaan media Teleng ini di dalam 
materi konsep sistem gerak manusia; (2) pembelajaran yang menarik dan menyenangkan siswa dapat dilakukan dengan melibatkan siswa memilih dan membuat media pembelajaran; (3) media ini dapat dikembangkan dan disempurnakan untuk meningkatkan hasil belajar; (4) Perlu kiranya lebih menyemangati pendidik dalam mengembangkan ide kreatif dan inovatifnya sehingga mutu pendidikan dapat lebih dioptimalkan. Ini ditujukan bagi kepala sekolah, pengawas pendidikan, dan Dinas Pendidikan serta instansi yang terkait.

\section{PUSTAKA ACUAN}

Chou, C. C. "An Analysis of the 3D Video Interactive Response Approach Effects on the Science Remedial Teaching for Fourth Grade Underachieving Students." Eurasia Journal of Mathematics. Science and Tecnology Education 13 (4), 2017: $1059-1073$.

Kurniasih, Tjitjih. Sistem Organ Manusia. Yogyakarta: Daepublish, 2018.

Pawestri, Lia. "Pengembangan Model Rangka Manusia pada Pembelajaran IPA Kelas IV SD Bakulan." Jurnal Pendidikan Guru Sekolah Dasar Edisi 3 Tahun ke-5, 2016.

Rusman. Pembelajaran Tematik Terpadu. Depok: PT Rajagrafindo Persada, 2015.

Sadirman, S. Arif, dkk. Media Pendidikan. Jakarta: Raja Grafindo, 2012.

Sanjaya, Wina. Media Komunikasi Pembelajaran. Jakarta: Kencana Prenadamedia Group, 2014.

Sugiyono. Metode penelitian Pendekatan Kuantitatif, Kualitatif, dan R\&D. Jakarta: Alfabeta, 2017.

Trianto. Model Pembelajaran Terpadu. Jakarta: Bumi Aksara, 2015.

Wahyuni, Nurmeita Tri. Peningkatan Aktivitas dan Hasil Belajar Melalui Penggunaan Media Clay Materi Berkarya pada Siswa Kelas IV SDN 2 Karang Sentul Purbalingga. Semarang: UNS, 2013.

Widodo, S.A., Darhim, \& Ikhwanudin, T. "Improving Mathematical Problem Solving Skills Through Visual Media." Journal of Physics, 2018. 